\title{
Study of the protection of the architectural heritage of Russia
}

\author{
Elena Voskresenskaya ${ }^{*}$, Lybov Vorona-Slivinskaya ${ }^{2}$, and Yury Kazakov ${ }^{2}$ \\ ${ }^{1}$ Peter the Great St.Petersburg Polytechnic University, 195251, 29, Polytechnicheskaya str., St. \\ Petersburg, Russia \\ ${ }^{2}$ Saint Petersburg State University of Architecture and Civil Engineering, 190005, 4, 2nd \\ Krasnoarmeyskaya str., St. Petersburg, Russia
}

\begin{abstract}
The article covers the problems of protection of the architectural heritage of the Russian Federation, as it is spiritual, cultural, economic and social capital of unique value. Along with natural wealth, architectural heritage is the foundation of national self-esteem and recognition by the world. The post-industrial civilization realized the highest potential of the architectural heritage, the need for its preservation and efficient use as one of the most important resources of the world economy. Losses of architectural values are irreparable and irreversible. Any loss of historic-cultural landmarks will inevitably affect all areas of the life of present and future generations, will lead to cultural decadence, rupture of historical memory and social scarcity. They cannot be offset by the development of modern culture, or the creation of new significant works of art. The accumulation and protection of cultural capital is the basis for the development of any civilization. The preserved monuments breed cultural legacy and help to comprehend the today's world by following the timeless values and their development in art. Critical moments raise not only the interest in historical and cultural heritage but also sensitivity to the mistakes, which have led to irreparable losses of national values.
\end{abstract}

\section{Introduction}

The study of the protection of architectural heritage is carried out with comprehensive and system analysis. The subject boundaries are given by the range of works involved in the history of architecture, in which the cognitive potential of sociological, iconographic and iconological methods is conducted, these are studies of the architecture of buildings and complexes of socially and symbolically developed societies and cultures. The goal is to develop theoretical approaches to study the protection of architectural research and test them on specific objects. The results of the study indicated in the article are the identification of a number of problems:

1. lack of knowledge of the methods for historical and architectural research;

2. undeveloped in the historical and architectural study of the methodological framework for the study of research methods;

\footnotetext{
* Corresponding author: elenvoskr@mail.ru
} 
3. unadjustment of general scientific methods for architectural specificity.

The methodological concept of the comprehensive approach and some issues of its application in the study of the protection of architectural heritage are explained in [1-5]. The basics of a system approach analysis of the protection of historical and cultural landmarks are applied in the works [6-7]. The authors of the article also conducted research on the protection of architectural heritage in [8-9].

\section{Materials and Methods}

Modern study and methodology of architectural science has a wide range of tools for the research of specific scientific methods. In order to use them to scrutinize the methods of historical and architectural research, it is necessary to substantiate the choice of those methods that will, on the one hand, correspond to the object of study, and on the other hand, provide the most effective result of their use. Comprehensive and system types of methodological analysis were picked from the spectrum of scientific research methods. These methodologies are characterized by a high theoretical ground and relative universality; however, they are not adapted for today's historical and architectural unique features.

\section{Results}

According to information received from the regions, Russia had 56565 archaeological heritage sites of federal significance in 2017. The number of archaeological heritage sites identified in 2017 was 7327 units. Table 1 provides information on the objects of architectural heritage by subjects of the Russian Federation.

Table 1. The number of architectural heritage sites in the constituent entities of the Russian Federation.

\begin{tabular}{|c|c|c|}
\hline Constituent entity of the Russian Federation & Federal & Identified \\
\hline Belgorod Region & 908 & 593 \\
\hline Bryansk Region & 457 & 722 \\
\hline Vladimir Region & 360 & 535 \\
\hline Voronezh Region & 1311 & 1552 \\
\hline Ivanovo Region & 31 & 398 \\
\hline Kaluga Region & 7 & 1022 \\
\hline Kostroma Region & 751 & 88 \\
\hline Kursk Region & 78 & 1212 \\
\hline Lipetsk Region & 116 & 1961 \\
\hline Moscow Region & 118 & 1512 \\
\hline Oryol Region & 301 & no data \\
\hline Ryazan Region & 141 & 2197 \\
\hline Smolensk Region & 669 & 1081 \\
\hline Tambov Region & 64 & 773 \\
\hline Tver Region & 4927 & 869 \\
\hline Tula Region & 140 & 1898 \\
\hline Yaroslavl Region & 545 & 42 \\
\hline Federal city of Moscow & 155 & 0 \\
\hline Republic of Karelia & 1562 & 592 \\
\hline Komi Republic & 107 & 646 \\
\hline Arkhangelsk Region & 183 & 1 \\
\hline Nenets Autonomous Area & 1 & 51 \\
\hline Vologda Region & 16 & 2456 \\
\hline
\end{tabular}




\begin{tabular}{|c|c|c|}
\hline Constituent entity of the Russian Federation & Federal & Identified \\
\hline Kaliningrad Region & 149 & 25 \\
\hline Leningrad Region & 319 & 1466 \\
\hline Murmansk Region & 12 & 188 \\
\hline Novgorod Region & 1602 & 528 \\
\hline Pskov Region & 3708 & 0 \\
\hline Federal city of St. Petersburg & no data & no data \\
\hline Republic of Adygea & 165 & 3084 \\
\hline Republic of Kalmykia & 51 & 199 \\
\hline Krasnodar Region & 5112 & 9037 \\
\hline Astrakhan Region & 94 & 133 \\
\hline Volgograd Region & 1222 & 49 \\
\hline Rostov Region & 8057 & 990 \\
\hline Republic of Dagestan & 1833 & 333 \\
\hline Republic of Ingushetia & 118 & 0 \\
\hline Kabardino-Balkaria Republic & no data & no data \\
\hline Karachay-Cherkess Republic & no data & no data \\
\hline Republic of North Ossetia-Alania & 65 & 267 \\
\hline Chechen Republic & 26 & 227 \\
\hline Stavropol Region & 772 & 843 \\
\hline Republic of Bashkortostan & 1281 & 2374 \\
\hline Republic of Mari El & 445 & 63 \\
\hline The Republic of Mordovia & 68 & 51 \\
\hline Republic of Tatarstan & 268 & 2663 \\
\hline Udmurtia & 68 & 826 \\
\hline Chuvash Republic & 176 & 31 \\
\hline Perm Region & 1808 & 49 \\
\hline Kirov Region & 357 & 152 \\
\hline Nizhny Novgorod Region & 929 & 583 \\
\hline Orenburg Region & 1280 & 887 \\
\hline Penza Region & 20 & 0 \\
\hline Samara Region & 25 & 2409 \\
\hline Saratov Region & 98 & 3350 \\
\hline Ulyanovsk Region & 45 & 427 \\
\hline Kurgan Region & 709 & 467 \\
\hline Sverdlovsk Region & 269 & 1435 \\
\hline Tyumen Region & 100 & 990 \\
\hline Khanty-Mansi Autonomous Area - Ugra & 983 & 4262 \\
\hline Yamalo-Nenets Autonomous Area & 2 & 526 \\
\hline Chelyabinsk Region & 265 & 1467 \\
\hline Altai Republic & 109 & 0 \\
\hline The Republic of Buryatia & 755 & 402 \\
\hline Tyva Republic & 730 & 19 \\
\hline The Republic of Khakassia & 1064 & 811 \\
\hline Altai Region & 2254 & 0 \\
\hline
\end{tabular}

Unfortunately, as it had been earlier, in 2017 it was customary for local authorities to delay the State registration of identified archaeological heritage sites. As a result, in recent years, tens of thousands of newly identified objects of the archaeological heritage have not been included into the State accounting system, which negatively affected their condition, and in some cases led to their loss.

In 2017, the Ministry of Culture of the Russian Federation issued 1845 archaeological excavation permits to perform archaeological works, including excavation works in the 
territory of new constituent entities of the Russian Federation: the Republic of Crimea (50 permits) and federal city of Sevastopol (18 permits).

Table 2 presents information on the sites of historical and cultural heritage in the Russian Federation.

Table 2. Historic and cultural heritage sites in the Russian Federation (thousands).

\begin{tabular}{cccc}
\hline Number of the sites & $\mathbf{2 0 1 5}$ & $\mathbf{2 0 1 6}$ & $\mathbf{2 0 1 7}$ \\
\hline Number of cultural heritage sites - total & $\mathbf{9 8 . 5}$ & $\mathbf{9 8 . 2}$ & $\mathbf{9 8 . 7}$ \\
including & & & \\
monuments & 91.4 & 90.1 & 88.5 \\
ensembles & 4.6 & 5.8 & 8.3 \\
places of interest & 0.9 & 2.3 & 1.9 \\
Number of archaeological heritage sites & 72.5 & 69.8 & 59.4 \\
\hline
\end{tabular}

In 2017, scientific excavations were carried out at 175 sites of the archaeological heritage ( 86 sites of federal significance and 89 identified sites). Rescue excavations were carried out at 439 sites of archaeological heritage (252 sites of federal significance and 187 identified sites).

The Ministry of Culture of the Russian Federation allocates funds for rescue excavations of the major sites of the archaeological heritage. The cultural heritage of the Russian Arctic is not only of scientific, historical and cultural importance. Objects of cultural heritage located on the coast, islands and archipelagoes of the Russian Arctic confirm the advantages of Russia in the development of the northern territories. Preserving the cultural heritage of the Russian Arctic is a necessary element of the system of measures to ensure state security in the Arctic region. The Government Decree of April 21, 2014 No. 366 "On Approval of the State Program of the Russian Federation "Socio-Economic Development of the Arctic Zone of the Russian Federation for the Period up to 2020" clearly outlines the priorities of our country in the development of the Arctic area. The "Preservation of the cultural heritage of the Russian Arctic" subprogram should become one of the key tools for the study and development of this zone.

In 2017, 263 sites of archaeological heritage (154 sites of federal significance and 109 identified sites) were excavated fully. Part of 266 objects of archaeological heritage (123 sites of federal significance and 123 identified sites) are susceptible to destruction. Scientific and preserving excavations were carried out at less than $2 \%$ of the total number of archaeological heritage sites. In the meantime, $80 \%$ of the sites of the archaeological heritage of the peoples of the Russian Federation were examined only by eye.

In 2017, 37 archeological monuments were removed from the register, of which 26 were fully investigated, 11 were destroyed by external factors, mainly of natural origin. One monument is excluded from the register according to monitoring data. 43,488 archaeological heritage sites are in satisfactory condition (18,344 sites of federal significance, 25,144 identified sites). There are 17,289 archaeological heritage sites in unsatisfactory condition (7,864 federal sites, 9,425 identified sites).

3,171 objects of archaeological heritage are in a ruined state: (855 sites of federal significance, 2316 identified sites). There are no data on the state of 31,229 landmarks (14,402 sites of federal significance, 16,827 identified sites). Objects of the archaeological heritage are influenced by natural and anthropogenic factors, when natural factors are especially destructive. This is mainly water and wind erosion, landslides of the banks of reservoirs. In turn, the most dangerous social phenomenon in the field of the protection of historic and cultural heritage is pillaging, which has a significant impact on the entire social and cultural life of Russia. 


\section{Discussions}

In 2017, 663 million rubles were spent to preserve the objects of the archaeological heritage: federal budget - 28.169 million rubles, local budgets - 362.795 million rubles, non-budgetary sources - 272.314 million rubles.

As part of the implementation of the organizational and financial plan of the federal target program "Culture of Russia (2012-2018)" for 2017 (approved by order No. 338 of the Ministry of Culture of the Russian Federation dated February 26, 2014), 45 projects totaling 28,169,600 rubles were completed, including:

1. "Inventory of sites of the archaeological heritage": 8 projects for a total amount of $6,359,600$ rubles;

2. "Archaeological excavations": 24 projects totaling 1,454,000 rubles;

3. "Monitoring over the state and use of archaeological heritage sites": 13 projects totaling $7,270,000$ rubles.

Table 3 presents data on the number of historical and cultural landmarks in 2011-2013.

Table 3. Historical and cultural landmarks in 2011-2013 (thousands).

\begin{tabular}{|c|c|c|c|}
\hline Number of landmarks & $\mathbf{2 0 1 1}$ & $\mathbf{2 0 1 2}$ & $\mathbf{2 0 1 3}$ \\
\hline Number of historical and cultural landmarks & $\mathbf{1 8 5 . 1}$ & $\mathbf{1 7 5 . 9}$ & $\mathbf{1 8 0 . 1}$ \\
\hline including the landmarks of: & 78.0 & 78.9 & 82.2 \\
\hline archeology & 31.1 & 29.4 & 30.7 \\
\hline history & 70.1 & 61.8 & 61.4 \\
\hline art & 4.9 & 3.7 & 4.1 \\
\hline town development and architecture
\end{tabular}

In total, in 2017, the following measures were taken to preserve the archaeological heritage sites: design and survey works at 413 sites, rescue excavations at 439 sites, emergency works at 6 sites.

In 2017, the cultural heritage protection authorities issued 26 prescriptions for the suspension of construction work on the territory of the archaeological heritage. 45 legal entities and individuals were brought to administrative responsibility for violation of the legislation of the Russian Federation in relation to the landmarks of the archaeological heritage.

The state of the archaeological heritage, the attitude of authorities and citizens towards it are an indicator of the attitude of society towards its past, towards its history, what is the bedrock of love for the nation.

\section{Conclusions}

The Federal Law "On the Objects of Cultural Heritage (Historical and Cultural Landmarks) of the Peoples of the Russian Federation" regulates relations in the field of preservation, use, promotion and state protection of cultural heritage objects (historical and cultural landmarks) and is aimed at the implementation of the constitutional right of everyone to access to cultural values constitutional duty of everyone to preserve the historical and cultural heritage, to preserve historical and cultural monuments, as well as to comply with the rights of peoples and other ethnic communities in the Russian Federation for the preservation and development of their cultural and national identity, protection, restoration and preservation of historical and cultural environment, protection and preservation of sources of information about the origin and development of culture.

In July 2013, the Federal Law No. 245 "On Amendments to Certain Legislative Acts of the Russian Federation Regarding the Suppression of Illegal Activities in the Field of Archeology" was adopted. The law provides for an important standard, which restricts the 
scope of individuals and legal entities entitled to conduct archaeological excavations. An important point is to bring the national legislation in compliance with the requirements of the European Convention on the Protection of the Archaeological Heritage in terms of establishing control over the use of metal detectors and other search equipment. It provides for criminal responsibility for the illegal search and removal of archaeological objects from the sites, administrative responsibility for the illicit trafficking of archaeological objects, imposes restrictions on the use of search equipment, and establishes liability for the violation of these restrictions.

It is fundamentally important to note that as part of the implementation of the norms of the Federal Law No. 245 dated July 23, 2013 "On Amendments to Certain Legislative Acts of the Russian Federation Regarding the Suppression of Illegal Activities in the Field of Archeology", the Ministry of Culture of Russia developed the Rules for issuing, suspending and terminating permits to carry out work on the identification and study of objects of the archaeological heritage. The specified rules are approved by the Decree of the Government of the Russian Federation No. 127 dated February 20, 2014.

Recorded cases of pillaging in the Russian Federation indicate a lack of information from the regions, as well as a lack of funds to monitor over the state of the archaeological heritage sites. Information about the recorded illicit excavations are provided by the bodies of protection of historical and cultural monuments of the Republic of Adygea and the Orenburg Region only. The lack of specialists in various types of cultural heritage affects the quality of information, and some tables for this reason do not contain indicators at all. Funding tables are often filled by employees who do not have full information. 48 constituent entities of the Russian Federation do not have data on the financing of measures for the protection of the archaeological heritage.

\section{References}

1. E. A. Maltseva, State Ecological Expertise: Problems and Contradiction of Existing Environmental Law Standards, 2, 19-32 (2014)

2. M. V. Matveeva, Environmental review as a stage in the development of land development, 4, 33-36 (2013)

3. S.I. Sai, State Ecological Expertise in Russia: Formation, Destruction, Revival, 6, 16-20 pp. (2014)

4. D. V. Khustov Problems of legal regulation of environmental impact assessment at the present stage, 5, 29-44 p (2012)

5. E. Voskresenskaya, V. Snetkov, A. Tebryaev, V E3S Web of Conferences 33, 03051 (2018) doi.org/10.1051/e3sconf/20183303051

6. E. Voskresenskaya, N. Zhilskiy, E. Shariapova, Matec web of conferences (2018) DOI https://doi.org/10.1051/matecconf/201817001057

7. E. Voskresenskaya, D. Mokhorov, A. Tebryaev, Matec web of conferences, 170 (2018) DOI https://doi.org/10.1051/matecconf/201817001058

8. E. Voskresenskaya, V. Snetkov, A. Tebryaev, Z, Askarov, MATEC Web of Conferences (2017)

9. E. Voskresenskaya, L. Vorona-Slivinskaya, V E3S Web of Conferences 33, 03052 (2018) https://doi.org/10.1051/e3sconf/20183303052 